from the boiler of a portable engine about twenty years old. Microscopic examination showed that the effect of fatigue stresses on the plate had been to form cracks commencing as a rule from irregularities on the inner surface, which cracks were due to weakness in the cleavage planes of the crystals from continual slipping, and to a less degree to some loss of adhesion between the crystals. Some of the crystals appeared to have been broken up, and the slag flaws seemed to have a restraining effect on the progress of the cracks.

Mr. B. H. Thwaite (London) directed attention to accidents due to the asphyxiation of blast-furnace workmen, and described an apparatus for the rapid detection of the presence of carbon monoxide in air.

Prof. F. Wüst and Mr. F. Wolff (Aachen) submitted a paper on the behaviour of sulphur in the blast furnace. They showed that, contrary to the generally held opinion, the sulphur in the coke does not reach the level of the tuyeres of the blast furnace without undergoing alteration, but a great portion of it is previously volatilised by the ascending gases. It is then largely absorbed from the gases by the descending charge, and in this condition arrives in front of the tuyeres. $\mathrm{Up}$ to $800^{\circ}$ the sulphur is principally absorbed by the oxides of iron from the sulphur-laden gases, while from $800^{\circ}$ upwards the position is reversed, and the lime becomes the chief absorbent of the sulphur.

Reports of research work carried out during the past year by Dr. H. C. H. Carpenter (National Physical Laboratory), by Mr. J. C. Gardner (Birmingham), by Mr. F. Rogers (Cambridge), and by Mr. Gunnar Dillner and Mr. A. F. Enström (Stockholm), holders of the Carnegie research scholarships, were submitted. Dr. Carpenter dealt with the types of structure and the critical ranges on heating and cooling high-speed tool steels under varying thermal treatment.

In the light of the author's experiments the rationale of the advantageous presence of tungsten and molybdenum in high-speed tool steels appears fairly evident. The action of either of these elements consists in hindering, under certain conditions, and in altogether preventing, under suitably chosen conditions, changes in iron carbon alloys which would have for their result the softening of the material and its consequent unfitness for tool steel use. By suitable heat treatment it is possible to arrest the softening process at any desired stage, and thus obtain an alloy of any desired hardness. The metallographical results of the investigation are extremely interesting. They show that in spite of comparatively large percentages - up to 17 per cent. or 18 per cent.-of special elements, iron and carbon still remain as the all-important factors in determining the types of structure of high-speed tool steels. Except that the polyhedral or "austenitic" type of structure has never been obtained alone in a pure carbon steel, the types of the high-speed tool steels might all be obtained from pure iron carbon steels by appropriate thermal treatment. The austenitic structure appears to be that of the nose of the tool in actual use. Put briefly, the hardening of rapid tool steels at the present time appears to involve two factors, viz. (I) the widening, splitting, or lowering of the critical ranges by the special alloy element, and (2) the complete, or practically complete, suppression of the widened, split, or lowered range by a mild quenching, e.g. in an air-blast.

Mr. G. Dillner and Mr. A. F. Enström dealt with the magnetic and electric properties of sheet steel and steel castings. The results obtained have rendered it possible to make some comparisons as to the relative suitability of the different methods for producing a soft steel for electrotechnical purposes (sheet material). It has appeared that Bessemer steel has a lower magnetic quality than open-hearth steel. On comparing basic and acid openhearth steel, the basic steel has been found to be preferable and scarcely inferior to Lancashire iron. The reason why the Bessemer material is inferior in quality to the openhearth sheets may possibly be that the Bessemer steel has a greater opportunity of dissolving gases when the air is passed through the bath of molten metal. In general, basic steel does not contain such large quantities of silicon and manganese as acid steel, and at the same time it is possible to get a lower percentage of carbon in the first mentioned NO 1855 , voL. 72$]$ metal; these facts may cause the hysteresis loss to be lower in basic than in acid steel.

Mr. J. C. Gardner dealt with the effects caused by the reversal of stresses in steel, and Mr. F. Rogers submitted memoirs on troostite and on the heat treatment of steel.

It was announced that Andrew Carnegie research scholarships for this year, of $50 l$. each, were awarded to P. Breuil (Paris), Dr. H. C. H. Carpenter (National Physical Laboratory), E. G. L. Roberts and E. A. Wraight (London), and W. Rosenhain (Birmingham), and that scholarships, each of the value of rool., were awarded to H. C. Boynton (Cambridge, U.S.A.), L. A. Guillet (Paris), and $\mathrm{W}$. H. Hatfield (Sheffield).

The council carefully examined the reports of the research work carried out by the holders of the Carnegie research scholarships during the past year, and decided that the report prepared by Dr. H. C. H. Carpenter (National Physical Laboratory) was deserving of the gold medal. The council also decided that special silver medals should be awarded for the research carried out conjointly by Mr. Gunnar Dillner and Mr. A. F. Enström (Stock holm). The researches submitted by $\mathrm{Mr}$. Gardner and Mr. Rogers were highly commended. The medals were presented by $\mathrm{Mr}$. Carnegie at the banquet on May I2 $_{2}$ at the Hotel Cecil, when 500 gentlemen were present.

During the meeting it was announced that $\mathrm{Mr}$. Carnegie would give to the institute a further sum of 5000 . to cover the cost of printing the reports submitted by the Carnegie research scholars.

\section{HIGHER EDUCATION IN LONDON.}

I ECENT events inspire hope in the future of higher education in London. The report presented by Sir Arthur Rücker, F.R.S., principal of the University of London, at the celebration of presentation day on May ro, and the speech of Lord Londonderry in proposing "The Institution of Mining and Metallurgy "at the annual dinner of its members, are both highly encouraging and indicative of the growing importance attached in the metropolis to education of university standing, especially in science and technology.

Sir Arthur Rücker, in the course of his report, dealt in detail with the operations of the University of London, and was able to show that some of the preliminary work done since the re-organisation of the university has begun to bear fruit in the academic year now approaching its termination, and that the activity of the university has been extended in several directions. The question of the conditions of entrance to universities has been prominently before the public during the year, and a very important step has been taken by the Universities of Oxford, Cambridge, and London, which have agreed upon a scheme for the mutual recognition of the certificates given for their respective entrance examinations. Already twentyfive persons have been matriculated as students of London University under this agreement. Considerable progress has been made, also, with the project for the concentration of the teaching of the preliminary and intermediate studies of medical students in a few centres under the control of the university. Arrangements are in progress under the auspices of the university for establishing centres at University and King's Colleges, and Mr. Alfred. Beit has given a munificent donation of $25,000 l$. in aid of the scheme for the establishment of a third centre on the South Kensington site. It is much to be hoped that this generous gift will be supported by other large subscriptions. It is a matter of vital interest to the public that the unique opportunities for medical education afforded by the great metropolitan hospitals shall not be wasted, and, if they are to be utilised, it is essential that the whole curriculum of medical education shall be easily accessible to London. It is necessary, continued Sir Arthur Rücker, that medical education shall receive public help similar to that which is ungrudgingly given to engineering. It is not too much to say that medical men do more unpaid work for the public than do the members of any other profession, and that, in return, less help has been given by the public to medical education, in London at all events, than to any other of the principal branches of applied science. Large as the gifts to the university are, 
it is unfortunately true that much money is needed to make up for the neglect of university teaching in London in the past. Though the increase in the Government grant to university colleges will be of great value, the equipment of both University and King's Colleges needs improvement, and the salaries of the professors are quite inadequate. The whole question of retiring pensions, to which a private donor has just devoted $2,000,000 l$. in America, is untouched in London.

After the presentation for degrees at the University of London, there was a reception at Bedford College. The occasion is always one for the assembling of the friends of the higher education of women in London, and about five hundred guests were received by the principal, Mrs. James Bryce, and Mrs. Leonard Darwin. The students who were presented at the university included eight for science degrees. The college authorities are contemplating a great re-building scheme, for the lease of the present premises in Baker Street is almost on the point of expiring, and an appeal is being made for a quarter of a million sterling, of which roo,oool. would be devoted to endowing a college capable of accommodating five hundred students.

Lord Londonderry, in his speech at the annual dinner of the Institution of Mining and Metallurgy, referred to the work of the committee appointed by the Government to consider the coordination of the Royal College of Science at South Kensington with other institutions for higher scientific and technological instruction in London. An interim report has been presented by the committee. The Government has definitely informed the committee that, provided satisfactory arrangements can be arrived at for the due coordination of the work of the various higher scientific teaching institutions in London and elsewhere, and provided that guarantees are obtained for the adequate management of what will practically be a congeries of highly organised technical courses, and for the provision of a thoroughly satisfactory annual income for the upkeep of a great centre for this higher work, the Government is prepared to entrust the management of the Royal College of Science, including the Royal School of Mines, to a committee to be newly established for the purpose. This procedure, it is expected, will bring the work of the Royal College and School of Mines into the closest possible relations with that of the other higher teaching. institutions, so that a higher degree of cooperation and coordination may be attained in this important portion of the educational field. Lord Londonderry announced that he has good grounds for believing that the Chancellor of the Exchequer has been considering the financial aspect of the new condition of things that will be brought about in regard to the Royal College of Science if the changes outlined actually take effect, and that a reasonable increase in the sums at present annually devoted towards the expenses of the Royal College of Science will be made. Thus the Royal College, in its immensely enhanced possibilities of usefulness owing to its large new buildings, will be able to bring to the common aim, not only its fabric and its excellent equipment, and, of course, its good will and prestige, but also a satisfactory annual income as a substantial contribution to what must be the heavy annual expenditure involved in the great work to be carried on for higher scientific and technological education in the metropolis.

As Mr. Haldane, the chairman of the committee referred to by Lord Londonderry, said on the same occasion, there is now a prospect of the establishment of such a school of mining and metallurgy as will make London the first city of the Empire in point of education in these matters.

\section{UNIVERSITY AND EDUCATIONAL INTELLIGENCE.}

CAMBRIDGE.-Some five or six years ago a special committee was called together at Cambridge, and an effort was made to obtain the cooperation of the colleges and the town and county councils in a scheme for the improvement of the milk supply of Cambridge. The committee had as its primary object the eradication of tuberculosis, beginning with bovine tuberculosis, from the county of NO. I 855 , VOL. 72$]$
Cambridge. Concurrently it took up the question of the housing of cattle, the sterilisation of milk, the methods of storage and distribution of milk, and the question of what milk should be refused by the colleges and by private purchasers. All these points were considered, not only with regard to tuberculosis, but also in connection with other infectious diseases, e.g. diphtheria, scarlet fever, and typhoid fever. The Cambridge Town Council undertook to pay the expenses of a veterinary surgeon, and the following colleges undertook to consider the matter favourably, and in most cases offered a certain annual subvention :--Gonville and Caius, Trinity Hall, King's, Christ's, Sidney, Emmanuel, Downing, and Girton, but the larger colleges stood out, and the scheme fell through.

Prof. Woodhead, in an interesting article in the Cambridge Review of last week, raises the question whether some such scheme should not be revived, and points to the recent outbreak of scarlet fever, which was especially prevalent in one or two colleges, as an instance of a disease which might easily have been avoided if the community had taken proper precautions.

It is proposed to erect a building containing examination rooms on a site on the north-east corner of the museum grounds. At present the university is put to great cost in hiring rooms which, apart from their expense, are not well adapted for examinations. The syndicate appointed to consider this question estimates that for a sum of $7500 l$. it could provide for all examinations held in the university throughout the year, except, perhaps, for a week or two in June and December.

The Vice-Chancellor announces the generous offer of the Drapers' Company to find the sum of $5000 l$. towards the cost of a building for the department of agriculture provided that a further sum of $5000 \mathrm{l}$. is raised by voluntary subscriptions by the end of the current year.

The long vacation course in pathology, public bealth, and pharmacology will begin on Monday, July 3. Special courses of lectures have been arranged on phagocytosis, by Prof. Woodhead, with the assistance of Mr. W. Malden; on illness caused by unsound food, by Mr. H. E. Durham; on diphtheria, agglutinins, precipitins and hæmolysins, by Mr. G. S. Graham-Smith; and on protozoa and protozoal diseases, by Dr. Nuttall. Further information about these courses may be obtained by writing to Prof. Woodhead, The Museums, Cambridge.

Special courses on physiology, osteology, human anatomy, and histology will be given during the long vacation by Mr. Barcroft and Mr. Cole, Dr. Barclay-Smith, Dr. A. Hill, and Mr. Manners-Smith. These will begin on July 5 .

The jubilee of Cheltenham Ladies' College was celebrated on Saturday last, and a new science wing was declared open. The new laboratories and lecture-rooms have been erected at a cost of $18,000 l$, and include rooms well equipped for the teaching of physics, chemistry, and botany.

THE following resolution was carried at a meeting of the council of the Royal College of Surgeons of England, held on Thursday last:-" That it be referred to the Committee of Management to consider and report as to the desirability of treating chemistry, physics, and biology as subjects of preliminary education, and of requiring that an examination in them should be passed before the recognition of the commencement of medical studies, and to report further as to the desirability of the two colleges approaching the Universities and other examining bodies with the view of adopting a five years' curriculum of professional study from the date of passing the Preliminary
Science Examination."

AN entrance scholarship in science, value $48 \mathrm{l}$. for three years, will be awarded by the council of Bedford College for Women (University of London) on the result of an examination to be held June 28-30. Full particulars can be obtained from the principal, and forms of entry must be received by June 12 . The council, on the recommendation of the Reid trustees, will award the Reid fellowship in June to a graduate of the University of London who is also an associate of Bedford College. Applications should 